\title{
Antibacterial Activity of Defatted and Nondefatted Methanolic Extracts of Aframomum melegueta K. Schum. against Multidrug- Resistant Bacteria of Clinical Importance
}

\author{
Olufunmiso Olusola Olajuyigbe $\mathbb{D}^{1,2}$ Otunola Adedayo $\left.{ }^{1 D}\right)^{3}$ \\ and Roger Murugas Coopoosamy $\mathbb{D}^{2}$ \\ ${ }^{1}$ Department of Microbiology, Babcock University, PMB 4005, Ilisan-Remo, Ogun State, Nigeria \\ ${ }^{2}$ Department of Nature Conservation, Mangosuthu University of Technology, Durban, KwaZulu-Natal, South Africa \\ ${ }^{3}$ Department of Microbiology, Kwara State University, Ilorin, Kwara State, Nigeria
}

Correspondence should be addressed to Otunola Adedayo; oadedayo@gmail.com

Received 28 December 2019; Revised 11 May 2020; Accepted 22 June 2020; Published 6 August 2020

Academic Editor: Antonio M. Rabasco

Copyright (c) 2020 Olufunmiso Olusola Olajuyigbe et al. This is an open access article distributed under the Creative Commons Attribution License, which permits unrestricted use, distribution, and reproduction in any medium, provided the original work is properly cited.

\begin{abstract}
The antibacterial activity of the extracts of Aframomum melegueta including $n$-hexane extract (NHE), nondefatted methanol extract (NDME), and defatted methanol extract (DME) was investigated in this study. The NHE exhibited no antibacterial activity. The DME showed higher antibacterial activity than the NDME against the different isolates. At the highest concentration of $10 \mathrm{mg} / \mathrm{mL}$ in agar diffusion, NDME produced inhibition zones ranging from 11 to $29 \mathrm{~mm}$ against the microorganisms while DME produced inhibition zones ranging from 20 to $40 \mathrm{~mm}$ with the concentration of $10 \mathrm{mg} / \mathrm{mL}$ against the microorganisms. $0.1 \mathrm{mg} / \mathrm{mL}$ of the DME produced inhibition zones ranging between 12 and $14 \mathrm{~mm}$ in Aeromonas hydrophila ATCC 35654 and Pseudomonas aeruginosa ATCC 15442, respectively, while none of the isolates were inhibited by the NDME at a concentration of $1 \mathrm{mg} / \mathrm{mL}$ or less. In the agar dilution assay, the MICs of the NDME and DME ranged between 0.31 and $10 \mathrm{mg} / \mathrm{mL}$, but more isolates were inhibited at $0.31 \mathrm{mg} / \mathrm{mL}$ of DME than those in NDME. In macrobroth assay, the MICs of the NDME ranged between 0.15 and $5.0 \mathrm{mg} / \mathrm{mL}$ and the MBCs ranged between 0.63 and $5.0 \mathrm{mg} / \mathrm{mL}$, and the MICs of the DME ranged between 0.08 and $5.0 \mathrm{mg} / \mathrm{mL}$ and the MBCs were between $0.31 \mathrm{and} 5.0 \mathrm{mg} / \mathrm{mL}$. This study indicated that DME was more active with higher antibacterial activity than the NDME of this plant, and extracting the fatty portion of plant materials prior susceptibility testing would allow plant extracts to be more effective as well as justifying the use of Aframomum melegueta in traditional medicine for the treatment of bacterial infections.
\end{abstract}

\section{Introduction}

Medicinal plants have been used for centuries as remedies for human diseases because they contain components of therapeutics value. Recently, some higher plants' phytochemicals have been exploited as antimicrobials because they are biodegradable and not deleterious to human health [1] and highly acceptable [2]. The plant kingdom, for a long time, has, therefore, served as a prolific source of helpful drugs, food additives, flavoring agents, binders, and lubricants. It was estimated that about $25 \%$ of all prescribed medicines today are substances derived from plants [3]. While the acceptance of traditional medicine as an alternate form of health care encouraged researchers to further investigate antimicrobial activity of many plants, the use of herbal medicine, in the treatment and prevention of diseases, predating the introduction of antibiotics and other modern drugs [4], has continued to attract more attention to scientists worldwide [5], and more than $80 \%$ of the population in developing countries of the world depend on traditional herbal medicine [6].

In addition to this, emergence, persistence, and spread of multidrug-resistant (MDR) bacteria or "superbugs" [7] have 
posed a serious global threat of growing concern to treatment of infections. The "superbugs" denoting microorganisms with higher morbidity and mortality rate have increased due to several mutations that resulted in resistance to various classes of antibiotics. This is, on the other hand, due to the use and misuse of antimicrobials, enhanced global migration, increased use of antibiotics in clinics and animal production, selection pressure, poor sanitation, wildlife spread, and poor sewerage disposal system $[8,9]$. In medical arena, the increased antibiotic resistance has become a major threat to public health as effectiveness of antimicrobial treatments has reduced drastically while morbidity, mortality, and health care cost have increased significantly. While the death of the golden era of antibiotics resulted from the inability of researchers to maintain the pace at which antibiotics are discovered in the face of emerging resistant pathogens [10] and persistent failure to develop or discover new antibiotics and nonjudicious use of antibiotics are the predisposing factors associated with the emergence of antibiotic resistance [11], there is the need to search for alternative means of treating microbial infections globally as success in treating infectious diseases depends on the discovery of new and more antimicrobial compounds [12].

Aframomum melegueta K. Schum. is a species in the Zingiberaceae family. It is a spice commonly known as 'grains of paradise' [13], melegueta pepper, alligator pepper, guinea grains, or guinea pepper. It is a herbaceous perennial plant native to swampy habitats along the West African coast and an important cash crop in the southern part of Ethiopia [14]. Its trumpet-shaped purple flowers developing into 5 to $7 \mathrm{~cm}$ long pods containing numerous small, reddish-brown seeds. The average leaves are usually $35 \mathrm{~cm}$ in length and $15 \mathrm{~cm}$ wide. While the flowers are described as "handsome" aromatic with an orange colored lip and rich pinkish-orange upper part and the fruits contain numerous small golden red-brown seeds [15], the seed has a pungent odor, peppery, and slightly bitter taste [16] caused by aromatic ketones named 1-4-hydroxy-3-methoxyphenyl-decan-3-one [17]. The seeds have antimicrobial effects [18] and are used as a remedy for diarrhea, stomachache, rheumatism, inflammatory conditions, and postpartum hemorrhage [18-20].

Although various species of the Aframomum plants have been used as antidiarrhoea, anti-inflammatory, laxatives, for stomachache management, and as a tonic for sexual stimulation [21], El-Halawany et al. [22] indicated that Aframomum plants have antiulcer, antiplasmodial, antinociceptive, antimicrobial, and anticancer properties. The phytochemicals obtained from the seeds of $A$. melegueta have been used for years in the treatment of infectious diseases, and its grains possess active ingredients that may be exploited for local development of antimicrobials [23]. The antimicrobial activities have been attributed to the presence of phenols and phenolic compounds in its seeds [24] and terpenoids such as aframodial [25]. Amadi and $\mathrm{Wu}$, [26] reported that the potentials of phenols and terpenoids isolated from Aframomum plants have been well documented. Since the seed extracts exhibited antiseptic and bactericidal potentials locally, they play significant roles in treating wounds and in preventing infections [27]. Though there is dearth of information comparing antibacterial activity of fatted and defatted extracts of this plant, this study aimed at investigating the antibacterial activities of fatted and defatted methanolic extracts of $A$. melegueta seeds with those of some selected antibiotics widely used against bacterial infections.

\section{Materials and Methods}

2.1. Collection of Plant Material. Fresh fruits of Aframomum melegueta were purchased from a local market in Osun state, Nigeria. The fruits were sun-dried and authenticated at the Department of Basic Sciences, Babcock University, Ilisan Remo, Ogun State, Nigeria.

2.2. Test Microorganisms. Ten American Type Culture Collection (ATCC) pure cultures of bacteria were obtained from the Department of Microbiology and Biochemistry, University of Fort Hare, South Africa. The test organisms used include Micrococcus luteus, Pseudomonas aeruginosa ATCC 15442, Bacillus subtilis KZN, Plesiomonas shigelloides ATCC 51903, Aeromonas hydrophila ATCC 35654, Staphylococcus aureus NCTC 6571, Escherichia coli ATCC 25922, Klebsiella pneumoniae ATCC 10031, Pseudomonas aeruginosa ATCC 19582, and Klebsiella pneumoniae ATCC 4352. The isolates were maintained on nutrient agar at $4^{\circ} \mathrm{C}$.

2.3. Extract Preparation. The seeds of sun-dried A. melegueta were collected and further air-dried at room temperature before being pulverized in a mill (Christy Lab Mill, Christy and Norris Ltd; Process Engineers, Chelmsford, England) and stored in a sterile air-tight container for further use. To prepare $n$-hexane extract (NHE), $400 \mathrm{~g}$ of the pulverized seeds was steeped in $1500 \mathrm{~mL}$ of $n$-hexane for $72 \mathrm{~h}$ with shaking (Stuart Scientific Orbital Shaker, UK). To prepare nondefatted methanol extract (NDME), $150 \mathrm{~g}$ of the seed powder was steeped in $1000 \mathrm{~mL}$ of methanol for $72 \mathrm{~h}$. To prepare defatted methanol extract (DME), the powdered seed material soaked in $n$-hexane was extracted and air-dried for three days before being soaked again in methanol for $72 \mathrm{~h}$. The steeped seed materials in all the solvent were extracted after the soaking period for two other consecutive times. The extracts from each preparation were combined, filtered through Whatman No. 1 filter paper and concentrated under reduced pressure at $40^{\circ} \mathrm{C}$ using a rotary evaporator (Laborota 4000-efficient, Heidolph, Germany). Each of the crude extracts collected was dried at room temperature to a constant weight. The resulting crude extracts were stored in desiccators containing silica beads to remove moisture from the extract until used for assay. The extracts were resuspended in each of the extracting solvents to yield a $40 \mathrm{mg} / \mathrm{mL}$ stock solution from which different concentrations were prepared for analysis.

2.4. Antibacterial Activities of the Standard Antibiotics and Those of the Extracts by Agar Diffusion Techniques. Each of the isolates was prepared by the colony suspension method [28]. The density of each strain's suspension was adjusted to 
equal that of the $0.5 \mathrm{McF}$ arland standards by adding sterile distilled water to give a resultant concentration of $1 \times 10^{7} \mathrm{cfu} / \mathrm{mL}$. The antibacterial activity was determined using the agar diffusion method according to the modified Kirby-Bauer diffusion technique $[29,30]$ by swabbing the Mueller Hinton agar (MHA) (Oxoids UK) plates with the resultant standardized overnight culture of each test isolate. Multidiscs containing different antibiotics including ofloxacin $(5 \mu \mathrm{g})$, ciprofloxacin $(5 \mu \mathrm{g})$, gentamicin $(10 \mu \mathrm{g})$, cefuroxime $(30 \mu \mathrm{g})$, ceftazidime $(30 \mu \mathrm{g})$, ampicillin $(10 \mu \mathrm{g})$, augumentin $(30 \mu \mathrm{g})$, and nitrofurantoin $(300 \mu \mathrm{g})$ were aseptically placed on the inoculated agar plates and incubated at $37^{\circ} \mathrm{C}$ for $24 \mathrm{~h}$. After $24 \mathrm{~h}$ of incubation, the plates were examined for zones of inhibition [31]. The diameter of the inhibition zones produced by the extracts were measured and interpreted using the Clinical and Laboratory Standard Institute zone diameter interpretative standards [32].

To determine the antibacterial activities of the different extracts, plates were prepared according to the modified Kirby-Bauer by swabbing the Mueller Hinton agar (MHA) (Oxoids UK) plates with the resultant standardized overnight culture of each test isolate before wells were bored into the sets of the inoculated agar medium with heat-sterilized $6 \mathrm{~mm}$ cork borer. The wells were filled with $100 \mu \mathrm{L}$ of different concentrations $(0.1,10$, and $100 \mathrm{mg} / \mathrm{mL})$ prepared for each of the extracts taking care not to allow spillage of the solutions onto the surface of the agar. The plates were allowed to stand for at least $30 \mathrm{~min}$ before being incubated at $37^{\circ} \mathrm{C}$ for $24 \mathrm{~h} \mathrm{[33].} \mathrm{After} 24 \mathrm{~h}$ of incubation, the plates were examined for zones of inhibition [31]. The diameter of the inhibition zones produced by the extracts were measured and interpreted using the Clinical and Laboratory Standard Institute zone diameter interpretative standards [32].

\subsection{Determination of the Minimum Inhibitory Concentrations} (MICs) of the Different Extracts by Agar Dilution Techniques. To determine the antibacterial activity of the extract by the agar dilution method as described by Afolayan and Meyer [34], different concentrations of the extract, $0.1 \mathrm{mg} / \mathrm{mL}$, $1.0 \mathrm{mg} / \mathrm{mL}$, and $10 \mathrm{mg} / \mathrm{mL}$, were prepared in molten Mueller Hinton agar maintained in a water bath at $50^{\circ} \mathrm{C}$. A loopful of each of the standardized bacterial cultures was aseptically inoculated into the solidified agar by stabbing. Two Mueller Hinton agar plates containing 5\% methanol representing the final methanol concentration in the test plates without the extract served as negative controls. Another two blank plate containing only Mueller Hinton agar served as negative controls. Plates were incubated at $37^{\circ} \mathrm{C}$ for $24 \mathrm{~h}$. Each test was done in duplicate, and any test agar plate lacking visible growth at the point of stabbing was considered the minimum inhibitory concentration of each of the extracts

\subsection{Determination of Minimum Inhibitory Concentrations} (MICs) of the Different Extracts by Macrobroth Dilution. The minimum inhibitory concentrations (MICs) for the two extracts were determined in duplicate by the macrobroth dilution method in Mueller Hinton broth according to the Clinical Laboratory Standardization Institute (CLSI) [35]. To determine the MICs of each extract, different concentrations $(0.02,0.04,0.08,0.16,0.3125,0.625,1.25,2.5,5.0$, and $10.0 \mathrm{mg} / \mathrm{mL}$ ) of each of the extracts were prepared by serial dilution in double-strength Mueller Hinton broth. After the serial dilution, each tube was inoculated with $100 \mu \mathrm{L}$ of each of the bacterial strains and incubated at $37^{\circ} \mathrm{C}$ for $24 \mathrm{~h}$. Blank Mueller Hinton broth was used as negative control. Each assay was performed two times. The MIC was defined as the lowest dilution that showed no bacterial growth in the Mueller Hinton broth.

\subsection{Determination of the Minimum Bactericidal Concentra-} tions (MBCs) of the Different Extracts. The minimum bactericidal concentrations (MBCs) were identified by determining the lowest concentration of antibacterial agent that reduces the viability of the initial bacterial inoculum by $\geq 99.9 \%$. Here, antibiotic-free nutrient agar plates were inoculated with one loopful of culture taken from each of the first two broth cultures that showed no growth and the first growth-containing tube in the MIC tubes. The MBC plates were incubated at $37^{\circ} \mathrm{C}$ for $24 \mathrm{~h}$. After the incubation periods, the lowest concentration of each of the extracts that did not produce bacterial growth on the solid medium was regarded as their MBC values. This observation was matched with the MIC test tubes that did not show evidence of growth after $48 \mathrm{~h}$ of incubation.

\section{Results}

With the exception of ofloxacin and ciprofloxacin to which all the isolates were susceptible and gentamicin to which two of the isolates were resistant, cefuroxime, ceftazidime, ampicillin, and augumentin were ineffective while nitrofurantoin was able to inhibit the growth of five of the isolates. While the ofloxacin produced inhibition zones ranging between 15 and $30 \mathrm{~mm}$, ciprofloxacin produced inhibition zones ranging between 16 and $25 \mathrm{~mm}$ as shown in Table 1 .

The antibacterial activities of the three extracts including $n$-hexane extract (NHE), nondefatted methanol extract (NDME), and defatted methanol extract (DME) are shown in Table 2. The NHE exhibited no antibacterial activity. This showed that the fatty portion of the plant extract had no antibacterial activity. The NDME, on the contrary, was able to inhibit the test isolates at an average level as compared with the DME that showed high potency and a better antibacterial activity against the different isolates. At the highest concentration of $10 \mathrm{mg} / \mathrm{mL}$, NDME produced inhibition zones ranging from 11 to $29 \mathrm{~mm}$, while the isolates were not susceptible at a concentration of $1 \mathrm{mg} / \mathrm{mL}$ or less. While DME produced inhibition zones ranging from 20 to $40 \mathrm{~mm}$ at the highest concentration of $10 \mathrm{mg} / \mathrm{mL}, 1 \mathrm{mg} / \mathrm{mL}$ of this extract produced inhibition zones ranging from 14 to $20 \mathrm{~mm}$ with the exception of S. aureus NCTC 6571 and Klebsiella pneumoniae ATCC 4352 that were resistant. Contrariwise, $0.1 \mathrm{mg} / \mathrm{mL}$ of the DME was able to produce inhibition zones ranging between 12 and $14 \mathrm{~mm}$ in Aeromonas hydrophila ATCC 35654 and Pseudomonas aeruginosa ATCC 15442, respectively. Other isolates were not susceptible to this extract at $0.1 \mathrm{mg} / \mathrm{mL}$. 
TABLE 1: Bacterial susceptibility to different standard antibiotic disks.

\begin{tabular}{|c|c|c|c|c|c|c|c|c|}
\hline \multirow[b]{2}{*}{ Organisms used } & \multicolumn{8}{|c|}{ Average inhibition zones $( \pm 1.00)$ produced by different standard antibiotics } \\
\hline & $\begin{array}{l}\text { OFL } \\
(5 \mu \mathrm{g})\end{array}$ & $\begin{array}{c}\text { CPR } \\
(5 \mu \mathrm{g})\end{array}$ & $\begin{array}{c}\text { GEN } \\
(10 \mu \mathrm{g})\end{array}$ & $\begin{array}{c}\text { CFR } \\
(30 \mu \mathrm{g}) \\
(\mathrm{mn}\end{array}$ & $\begin{array}{c}\text { CFZ } \\
(30 \mu \mathrm{g})\end{array}$ & $\begin{array}{c}\text { AMP } \\
(10 \mu \mathrm{g})\end{array}$ & $\begin{array}{c}\text { NIT } \\
(300 \mu \mathrm{g})\end{array}$ & $\begin{array}{c}\text { AUG } \\
(30 \mu \mathrm{g})\end{array}$ \\
\hline Micrococcus luteus & $15 \pm 1.00$ & $16 \pm 1.00$ & $16 \pm 1.00$ & $6 \pm 1.00$ & $6 \pm 1.00$ & $6 \pm 1.00$ & $15 \pm 1.00$ & $6 \pm 1.00$ \\
\hline Bacillus subtilis KZN & $26 \pm 1.00$ & $24 \pm 1.00$ & $25 \pm 1.00$ & $6 \pm 1.00$ & $6 \pm 1.00$ & $6 \pm 1.00$ & $27 \pm 1.00$ & $6 \pm 1.00$ \\
\hline Escherichia coli ATCC 25922 & $20 \pm 1.00$ & $20 \pm 1.00$ & $10 \pm 1.00$ & $6 \pm 1.00$ & $6 \pm 1.00$ & $6 \pm 1.00$ & $6 \pm 1.00$ & $6 \pm 1.00$ \\
\hline Staphylococcus aureus NCTC 6571 & $28 \pm 1.00$ & $25 \pm 1.00$ & $14 \pm 1.00$ & $21 \pm 1.00$ & $6 \pm 1.00$ & $6 \pm 1.00$ & $6 \pm 1.00$ & $6 \pm 1.00$ \\
\hline Klebsiella pneumoniae ATCC 4352 & $25 \pm 1.00$ & $25 \pm 1.00$ & $15 \pm 1.00$ & $6 \pm 1.00$ & $6 \pm 1.00$ & $6 \pm 1.00$ & $13 \pm 1.00$ & $6 \pm 1.00$ \\
\hline Aeromonas hydrophila ATCC 35654 & $15 \pm 1.00$ & $25 \pm 1.00$ & $15 \pm 1.00$ & $6 \pm 1.00$ & $6 \pm 1.00$ & $6 \pm 1.00$ & $15 \pm 1.00$ & $6 \pm 1.00$ \\
\hline Klebsiella pneumoniae ATCC 10031 & $25 \pm 1.00$ & $25 \pm 1.00$ & $13 \pm 1.00$ & $6 \pm 1.00$ & $6 \pm 1.00$ & $6 \pm 1.00$ & $6 \pm 1.00$ & $6 \pm 1.00$ \\
\hline Plesiomonas shigelloides ATCC 51903 & $15 \pm 1.00$ & $16 \pm 1.00$ & $6 \pm 1.00$ & $6 \pm 1.00$ & $6 \pm 1.00$ & $6 \pm 1.00$ & $6 \pm 1.00$ & $6 \pm 1.00$ \\
\hline Pseudomonas aeruginosa ATCC 15442 & $15 \pm 1.00$ & $14 \pm 1.00$ & $6 \pm 1.00$ & $6 \pm 1.00$ & $6 \pm 1.00$ & $6 \pm 1.00$ & $6 \pm 1.00$ & $6 \pm 1.00$ \\
\hline Pseudomonas aeruginosa ATCC 19582 & $30 \pm 1.00$ & $25 \pm 1.00$ & $15 \pm 1.00$ & $6 \pm 1.00$ & $6 \pm 1.00$ & $6 \pm 1.00$ & $15 \pm 1.00$ & $6 \pm 1.00$ \\
\hline
\end{tabular}

$\mathrm{Ofl}=$ ofloxacin; $\mathrm{Cpr}=$ ciprofloxacin; $\mathrm{Gen}=$ gentamicin; $\mathrm{Cfr}=$ cefuroxime; $\mathrm{Cfz}=$ ceftazidime; $\mathrm{Amp}=$ ampicillin; Aug = augumentin; Nit = nitrofurantoin .

Table 2: Antibacterial activity of the different extracts of Aframomum melegueta using agar well diffusion assay.

\begin{tabular}{|c|c|c|c|c|c|c|c|c|c|}
\hline \multirow[b]{3}{*}{ Organisms used } & \multicolumn{9}{|c|}{ Average inhibition zones $( \pm 1.0 \mathrm{~mm})$ produced by the different extracts of $A$. melegueta } \\
\hline & \multicolumn{3}{|c|}{ NHE } & \multicolumn{3}{|c|}{ NDME } & \multicolumn{3}{|c|}{ DME } \\
\hline & 10 & 1 & 0.1 & 10 & $\begin{array}{c}1 \\
(\mathrm{mg} / \mathrm{mL})\end{array}$ & 0.1 & 10 & 1 & 0.1 \\
\hline Micrococcus luteus & $6 \pm 1.00$ & $6 \pm 1.00$ & & $19 \pm 1.00$ & $6 \pm 1.00$ & & & & \\
\hline Bacillus subtilis KZN & $6 \pm 1.00$ & $6 \pm 1.00$ & & $29 \pm 1.00$ & & & $40 \pm 1.00$ & $15 \pm 1.00$ & $6 \pm 1.00$ \\
\hline Escherichia coli ATCC 25922 & $6 \pm 1.00$ & $6 \pm 1.00$ & $6 \pm 1.00$ & $14 \pm 1.00$ & & $6 \pm 1.00$ & $29 \pm 1.00$ & $14 \pm 1.00$ & $6 \pm 1.00$ \\
\hline Staphylococcus aureus NCTC 6571 & $6 \pm 1.00$ & $6 \pm 1.00$ & & $19 \pm 1.00$ & & $6 \pm 1.00$ & $23 \pm 1.00$ & $6 \pm 1.00$ & $6 \pm 1.00$ \\
\hline Klebsiella pr & & & & & & & & & \\
\hline Aeromonas hydrophila ATCC 35654 & $6 \pm 1.00$ & $6 \pm 1.00$ & $6 \pm 1.00$ & $20 \pm 1.00$ & $6 \pm 1.00$ & $6 \pm 1.00$ & $25 \pm 1.00$ & $16 \pm 1.00$ & $12 \pm 1.00$ \\
\hline Klebsiella pneumoniae ATCC 10031 & $6 \pm 1.00$ & $6 \pm 1.00$ & $6 \pm 1.00$ & $14 \pm 1.00$ & $6 \pm 1.00$ & $6 \pm 1.00$ & $20 \pm 1.00$ & $6 \pm 1.00$ & $6 \pm 1.00$ \\
\hline as shigelloides ATCC 51903 & & & & & & & & & \\
\hline Pseudomonas aeruginosa ATCC 15442 & $6 \pm 1.00$ & & & $20 \pm 1.00$ & & & $30 \pm 1.00$ & $20 \pm 1.00$ & $14 \pm 1.00$ \\
\hline Pseudomonas aeruginosa ATCC 19582 & $6 \pm 1.00$ & $6 \pm 1.00$ & $6 \pm 1.00$ & $16 \pm 1.00$ & $6 \pm 1.00$ & $6 \pm 1.00$ & $30 \pm 1.00$ & $15 \pm 1.00$ & $6 \pm 1.00$ \\
\hline
\end{tabular}

$\mathrm{NHE}=n$-hexane extract; NDME $=$ nondefatted methanol extract; DME $=$ defatted methanol extract.

In Table 3, the susceptibility of the bacterial isolates was compared using agar dilution and macrobroth dilution assays based on the fact that the extracts were thoroughly mixed in the respective media while the isolates had a direct contact with the extract in the macrobroth dilution. The agar dilution assay showed that NDME and DME inhibited the isolates at minimum inhibitory concentrations ranging from 0.31 to $10 \mathrm{mg} / \mathrm{mL}$. For the NDME, Pseudomonas aeruginosa ATCC 15442 was inhibited at the MIC of $0.15 \mathrm{mg} / \mathrm{mL}$, Micrococcus luteus, Escherichia coli ATCC 25922, Aeromonas hydrophila ATCC 35654, and Plesiomonas shigelloides ATCC 51903 had their MICs at $0.31 \mathrm{mg} / \mathrm{mL}$, Klebsiella pneumoniae ATCC 4352 had its MIC at $0.63 \mathrm{mg} /$ $\mathrm{mL}$, while Bacillus subtilis KZN, Staphylococcus aureus NCTC 6571, Klebsiella pneumoniae ATCC 10031, and Pseudomonas aeruginosa ATCC 19582 had their MICs at $5.0 \mathrm{mg} / \mathrm{mL}$. For the DME, Klebsiella pneumoniae ATCC 4352, Pseudomonas aeruginosa ATCC 15442, Aeromonas hydrophila ATCC 35654, Micrococcus luteus, and Plesiomonas shigelloides ATCC 51903 had $0.31 \mathrm{mg} / \mathrm{mL}$ as their MICs, Escherichia coli ATCC 25922 had an MICs of $0.63 \mathrm{mg} /$ $\mathrm{mL}$, Pseudomonas aeruginosa ATCC 19582, Klebsiella pneumoniae ATCC 10031, and Staphylococcus aureus NCTC 6571 had their $5.0 \mathrm{mg} / \mathrm{mL}$ as their MICs, while Bacillus subtilis $\mathrm{KZN}$ had MICs of $10 \mathrm{mg} / \mathrm{mL}$. In comparison, the MICs and MBCs were obtained from the macrobroth dilution. From the macrobroth dilution, while the MICs of the NDME ranged between 0.15 and $5.0 \mathrm{mg} / \mathrm{mL}$ and the MBCs ranged between 0.63 and $5.0 \mathrm{mg} / \mathrm{mL}$, the MICs of the DME ranged between 0.08 and $5.0 \mathrm{mg} / \mathrm{mL}$ and the $\mathrm{MBCs}$ were between 0.31 and $5.0 \mathrm{mg} / \mathrm{mL}$. The DMEs of the Aframomum melegueta was 50\% higher in antibacterial activity than those of the NDME.

\section{Discussion}

Plants have a long history of antibiotic usage for the cure of disease caused by microorganisms. Many extracts from different plants have been tested for their antimicrobial activities, but there are still many plants requiring more careful investigation to reveal their hidden potential(s). While increasingly difficult socioeconomic situations and unavailability of modern medicine at affordable prices have forced tropical and developing countries, recording high rate 
TABle 3: Antibacterial activities of NDME and DME of Aframomum melegueta as determined by both agar and macrobroth dilution techniques.

\begin{tabular}{|c|c|c|c|c|c|c|}
\hline \multirow[b]{3}{*}{ Organisms used } & \multicolumn{2}{|c|}{ Agar dilution } & \multicolumn{4}{|c|}{ Broth dilution } \\
\hline & \multirow{2}{*}{$\frac{\text { NDME }}{\text { MIC }}$} & \multirow{2}{*}{$\frac{\mathrm{DME}}{\mathrm{MIC}}$} & \multicolumn{2}{|c|}{ NDME } & \multicolumn{2}{|c|}{ DME } \\
\hline & & & $\begin{array}{r}\text { MIC } \\
(\mathrm{n} \\
\end{array}$ & $\mathrm{MBC}$ & MIC & $\mathrm{MBC}$ \\
\hline Micrococcus luteus & 0.63 & 0.31 & 0.31 & 0.63 & 0.15 & 0.31 \\
\hline Bacillus subtilis $\mathrm{KZN}$ & 10.0 & 10 & 5.0 & 10.0 & 5.0 & 5.0 \\
\hline Escherichia coli ATCC 25922 & 0.63 & 0.63 & 0.31 & 0.63 & 0.31 & 0.31 \\
\hline Staphylococcus aureus NCTC 6571 & 10.0 & 5.0 & 5.0 & 10.0 & 2.5 & 5.0 \\
\hline Klebsiella pneumoniae ATCC 4352 & 1.25 & 0.31 & 0.63 & 10.0 & 0.31 & 0.31 \\
\hline Aeromonas hydrophila ATCC 35654 & 0.63 & 0.31 & 0.31 & 1.25 & 0.15 & 0.31 \\
\hline Klebsiella pneumoniae ATCC 10031 & 10.0 & 5.0 & 5.0 & 1.25 & 2.5 & 5.0 \\
\hline Plesiomonas shigelloides ATCC 51903 & 0.63 & 0.31 & 0.31 & 0.63 & 0.15 & 0.31 \\
\hline Pseudomonas aeruginosa ATCC 15442 & 0.31 & 0.31 & 0.15 & 0.63 & 0.08 & 0.15 \\
\hline Pseudomonas aeruginosa ATCC 19582 & 10.0 & 5.0 & 5.0 & 10.0 & 2.5 & 5.0 \\
\hline
\end{tabular}

of infectious diseases, to rely on traditional medicines $[36,37]$, antimicrobial agents from medicinal plants are increasingly showing their potentials to cure invasive infections [38, 39]. Therefore, the acceptance of traditional medicine as an alternative form of health care and the development of microbial resistance to the available antibiotics has led scientists to investigate the antimicrobial activity of medicinal plants [40]. The medicinal plants are, thus, recognized as a source of new drugs and complementary medicines, neutraceuticals, pharmaceuticals, and intermediate chemicals for synthetic drugs and their versatile applications [41-43].

In this study, the antibacterial activity of the two different extracts against the various bacterial isolates showed the scientific validity of Aframomum melegueta being used traditionally as a medicine. The results indicated that defatted methanolic extract (DME) was more active with higher antibacterial activity than the nondefatted methanolic extract (NDME) of this plant. The activity of the NDME at the highest concentration of $10 \mathrm{mg} / \mathrm{mL}$ was equivalent to the activity of the DME at a concentration of $1 \mathrm{mg} / \mathrm{mL}$. Thus, DME inhibited the bacterial isolates at lower concentrations compared with what were obtained from the NDME. While their antibacterial activities may be attributed to the presence of 6-paragol and 6shogoal [17] as well as soluble phenolic and polyphenolic compounds in the seeds [44], intercalation of the extract with deoxyribonucleic acid (DNA) [45], and disturbance of the permeability barrier of the bacterial membrane structure [46]. Balakumar et al. [47] suggested that the extract components cross the cell membrane, interact with the enzymes and proteins of the membrane, and produce a flux of protons towards the cell exterior to induce changes and the ultimate death of the cells. Pandian et al. [48] and Srinivasan [49] indicated that the bacterial cell death could have resulted from the binding of epicatechin and catechin to positively charged lipid bilayer of Gram-positive bacteria, inhibition of metabolic enzymes, and interference with the synthesis of certain amino acids necessary for bacterial growth. Olajuyigbe et al. [50] also reported that the cell death from the bacteria treated with the extracts could have resulted from ultrastructural changes and breakdown of elemental components in the bacteria into different elements and leaked lipid and protein from the bacteria. Olajuyigbe et al. [51] further reported that the cell death resulted from the ability of the extracts to produce reactive oxygen species with deleterious effects. Since the bioactivity of extracts depends on the concentration used [52], the ineffectiveness of the extracts at lower concentrations may be attributed to the presence of lesser amounts of the antimicrobial compounds in the extracts.

Though NDME and DME, respectively, inhibited $60 \%$ of the isolates at concentrations ranging between 0.08 and $0.63 \mathrm{mg} / \mathrm{mL}$, DME showed a better antibacterial activity. This is contrary to minimum inhibitory concentration of $31.25 \mathrm{mg} / \mathrm{mL}$ against Bacillus cereus [53] and that of $1.51 \mathrm{mg} /$ $\mathrm{mL}$ against Enterococcus aerogenes, Staphylococcus aureus, and Proteus mirabilis [54] in the previous studies with $A$. melegueta. The difference in the antibacterial activity of NDME and DME could be attributed to the inhibitory effect of the fatty portion of the plant material. Since $n$-hexane extract showed no antibacterial activity and the antibacterial activity of the NDME was lesser than that obtained from the DME, the interaction and presence of the fatty portion of the plant could have resulted in antagonistic interactions with phytochemicals having significant antibacterial activities.

Though there is a dearth of information indicating the effects of fatty portion of plant material on the antibacterial activities of varied phytochemicals, there have been several reports on the antibacterial activities of $n$-hexane extracts (NHEs) of some other plants [55-57]. While the NHE of $A$. melegueta showed no antibacterial activity against the selected bacterial strains, the antibacterial activities of NDME and DME may be considered significant as Rios and Recio [58] suggested that extracts with MICs of $0.1 \mathrm{mg} / \mathrm{mL}$ have significant antibacterial activities but those with MIC greater than $1 \mathrm{mg} / \mathrm{mL}$ should be avoided. Fabry et al. [59] defined active crude extracts as those having MIC values $<8 \mathrm{mg} / \mathrm{mL}$. Hence, since lower MIC and MBC values indicate higher efficacy [60] and phytochemicals are routinely classified as antimicrobials when susceptibility tests had MICs in the range of $0.1-1.0 \mathrm{mg} / \mathrm{mL}$ [61], the MICs and MBCs of less than $1 \mathrm{mg} / \mathrm{mL}$, in this study, were considered to be of good activity for both NDME and DME. 


\section{Conclusions}

In conclusion, many medicinal plant extracts exert their antibacterial effects through the additive or synergistic action of several chemical compounds acting at single or multiple target sites associated with a physiological process. This study shows that extracting the fatty portion of plant materials with $n$-hexane prior to susceptibility testing could allow the effectiveness of the extracts to be brought to the fore since defatted extract was significantly more active than the nondefatted extract and justify the use of Aframomum melegueta in traditional medicine for the treatment of bacterial infections.

\section{Data Availability}

The data used to support the findings of this study are included within the article

\section{Conflicts of Interest}

The authors declare that they have no conflicts of interest.

\section{References}

[1] I. M. Villasenor, A. P. Caulas, M. P. Pascua, M. N. Sabando, and L. A. Soliven, "Bioactivity studies on Cassia alata Linn. leaf extracts," Phytotherapy Research, vol. 6, no. 1, pp. S93-S96, 2002.

[2] S. K. Ghimire, D. McKey, and Y. A.- Thomas, "Conservation of Himalayan medicinal plants: harvesting patterns and ecology of two threatened species, Nardostachys grandiflora DC. and Neopicrorhiza scrophulariiflora (Pennell) Hong," Biological Conservation, vol. 124, no. 4, pp. 463-475, 2005.

[3] J. M. Dalziel, The Useful Plants of West Tropical Africa, pp. 612-615, Crown Agents for the Colonies, London, UK, 1937.

[4] E. Haslam, E. H. Lilley, Y. A. Cai, R. Martin, and D. Magnolato, "Traditional herbal medicine. The role of polyphenols," Planta Medica, vol. 55, no. 1, pp. 1-8, 1989.

[5] O. Odebiyi and E. A. Sofowora, "Photochemical Screening of Nigerian medicinal plants II," Lloydia, vol. 41, no. 3, pp. 234-246, 1978.

[6] M. Eddouks, M. Maghrani, A. Lemhadri, M. L. Ouahidi, and H. Jouad, "Ethnopharmacological survey of medicinal plants used for the treatment of diabetes mellitus, hypertension and cardiac diseases in the southeast region of Morocco (Tafilalet)," Journal of Ethnopharmacology, vol. 82, no. 2-3, pp. 97-103, 2002.

[7] J. Davies and D. Davies, "Origins and evolution of antibiotic resistance," Microbiology and Molecular Biology Reviews, vol. 74, no. 3, pp. 417-433, 2010.

[8] A. C. Singer, H. Shaw, V. Rhodes, and A. Hart, "Review of antimicrobial resistance in the environment and its relevance to environmental regulators," Frontiers in Microbiology, vol. 7, p. 1728,2016

[9] B. M. Marshall and S. B. Levy, "Food animals and antimicrobials: impacts on human health," Clinical Microbiology Reviews, vol. 24, no. 4, pp. 718-733, 2011.

[10] C. Nathan and O. Cars, "Antibiotic resistance - problems, progress, and prospects," New England Journal of Medicine, vol. 371, no. 19, pp. 1761-1763, 2014.
[11] C. Nathan, "Antibiotics at the crossroads," Nature, vol. 431, no. 7011, pp. 899-902, 2014.

[12] J. H. Jorgensen and J. D. Turnidge, "Susceptibility test methods: dilution and disk diffusion methods," in Manual of Clinical Microbiology, P. R. Murray, E. J. Baron, J. H. Jorgensen, M. L. Landry, and M. A. Pfaller, Eds., ASM Press, Washington, D.C, USA., 9th edition, 2007.

[13] S. Umukoro and R. B. Ashorobi, "Further studies on the antinociceptive action of aqueous seed extract of Aframomum melegueta," Journal of Ethnopharmacology, vol. 109, no. 3, pp. 501-504, 2007.

[14] SNNPR, Southern Nations Nationalities and People's Region: Livelihood Profile (Regional Overview), SNNPR, Hawassa. Ethiopia, 2005.

[15] P. E. Beichner, "Grains of Paradise: Unofficial Varieties of Cardamom Seed in the 25th Edition of the Dispensatory of U.S.A," 1955.

[16] W. Iwu, A. R. Duncan, and C. O. Okwu, "New antimicrobials of plant origin," in Perspectives on New Crops and New Uses, J. Janick, Ed., pp. 457-462, ASHS Press, Alexandria, Egypt, 1999.

[17] A. M. Galal, "Antimicrobial activity of 6-paradol and related compounds," International Journal of Pharmacognosy, vol. 34, no. 1, pp. 64-69, 1996.

[18] S. Rafatullah, A. M. Galal, M. A. Al-Yahya, and M. S. Al-Said, "Gastric and duodenal antiulcer and cytoprotective effects of Aframomum melegueta in rats," International Journal of Pharmacognosy, vol. 33, no. 4, pp. 311-316, 1995.

[19] X. Fernandez, C. Pintaric, L. Lizzani-Cuvelier, A.-M. Loiseau, A. Morello, and P. Pellerin, "Chemical composition of absolute and supercritical carbon dioxide extract ofAframomum melegueta," Flavour and Fragrance Journal, vol. 21, no. 1, pp. 162-165, 2006.

[20] N. Ilic, B. M. Schmidt, A. Poulev, and I. Raskin, "Toxicological evaluation of grains of paradise (Aframomum melegueta) [roscoe] K. Schum," Journal of Ethnopharmacology, vol. 127, no. 2, pp. 352-356, 2010.

[21] J. A. Duke, CRC Handbook of Medicinal Spices, CRC Press, Boca Raton, FL, USA, 2002.

[22] A. M. El-Halawany, R. S. E. Dine, N. S. El Sayed, and M. Hattori, "Protective effect of Aframomum melegueta phenolics against $\mathrm{CCl} 4$-induced rat hepatocytes damage; role of apoptosis and pro-inflammatory cytokines inhibition," Scientific Reports, vol. 4, p. 5880, 2014.

[23] J. O. Oyagade, O. O. Awotoye, J. T. Adewunmi, and H. T. Thorpe, "Antimicrobial activity of some Nigerian medicinal plants, screening for antibacterial activity," Journal of Bioscience Research Communication, vol. 11, pp. 193-197, 1999.

[24] V. P. Devmurari, "Phytochemical screening study and antibacterial evaluation of symplocos racemosa Roxb. Scholarly research library," Archives of Applied Science Research, vol. 2, no. 1, pp. 354-359, 2010.

[25] J. F. Ayafor, M. H. K. Tchuendem, B. Nyasse, F. Tillequin, and H. Anke, "Novel bioactive diterpenoids from Aframomum aulacocarpos," Journal of Natural Products, vol. 57, no. 7, pp. 917-923, 1994.

[26] S. W. Amadi, Y. Zhang, and G. Wu, "Researh progress in phytoheistry and Biology of Aframomum species," Pharmaceutical Biology, vol. 54, no. 11, pp. 2761-2770, 2016.

[27] D. E. Okwu, "Phytochemicals and vitamin content of indigenous spices of South Eastern Nigeria," Journal of Sustainable Agriculture and the Environment, vol. 6, no. 2, pp. 30-34, 2004. 
[28] J. M. Andrews, "BSAC standardized disc susceptibility testing method (version 8)," Journal of Antimicrobial Chemotherapy, vol. 64, no. 3, pp. 454-489, 2009.

[29] CLSI, "Update on the 2012-2013 CLSI standards for antimicrobial susceptibility testing," in Edition -Susan Sharp, Clinical and Laboratory Standard Institute (CLSI), Wayne, PA:USA, 2012, http://www.swacm.org/annualmeeting/2012/ stlouisworkshops/WS4GPCLSIUpdate2012.pdf.

[30] G. Kaiser, Kirby-Bauer Test (Online Manual, Lab 21). SyllabusDepartment of Biology, Western Kentucky University, Bowling Green, KY, USA, 2012, http://student.ccbcmd.edu/ rgkaiser/index.html., faculty.ccbcmd.edu/courses/bio141/ labmanua/lab21/lab21.html.

[31] A. W. Bauer, W. M. M. Kirby, J. C. Sherris, and M. Turck, "Antibiotic susceptibility testing by a standardized single disk method," American Journal of Clinical Pathology, vol. 45, no. 4_ts, pp. 493-496, 1966.

[32] Clinical and Laboratory Standard Institute (CLSI), "Performance standards for antimicrobial susceptibility testing," in Eighteenth informational supplement. M100-S18 2008, Clinical and Laboratory Standard Institute (CLSI), Wayne, PA: USA, 2008.

[33] BSAC, British Society of Antimicrobial Chemotherapy, "Disc diffusion method for antimicrobial susceptibility testing," British Society for Antimicrobial Chemotherapy, vol. 2, pp. 1-46, 2002.

[34] A. J. Afolayan and J. J. M. Meyer, "The antimicrobial activity of 3,5,7-trihydroxyflavone isolated from the shoot of Helichrysum aureonitens," Journal of Ethnopharmacology, vol. 57, no. 3, pp. 177-181, 1996.

[35] S. Richard, S. M. Lynn, and C. G. Avery, Antimicrobial Susceptibility Testing Protocols, CRC Press, New York, NY, USA, 2007.

[36] V. Duraipandiyan, M. Ayyanar, and S. Ignacimuthu, "Antimicrobial activity of some ethnomedicinal plants used by Paliyartrive from Tamil Nadu, India," BMC Complementary and Alternative Medicine, vol. 6, p. 35, 2006.

[37] V. Kuete, J. Kamga, L. Sandjo et al., "Antimicrobial activities of the methanol extract, fractions ad compounds from Ficus polita Vahl. (Moraceae)," BMC Complementary Alternative Medicine, vol. 11, p. 6, 2011.

[38] D. S. Fabricant and N. R. Farnsworth, "The value of plants used in traditional medicine for drug discovery," Environmental Health Perspective, vol. 109, no. suppl 1, p. 69, 2001.

[39] M. Daglia, "Polyphenols as antimicrobial agents," Current Opinion in Biotechnology, vol. 23, no. 2, pp. 174-181, 2012.

[40] N. M. Rahmoun, Z. B. Atmani, M. Benabdallah, K. Boucherit, D. Vilemin, and N. C. Braham, "Antimicrobial activities of the henna extract and some synthetic naphtoquinones derivatives," American Journal of Medical and Biological Research, vol. 1, no. 1, pp. 16-22, 2013.

[41] K. Das, R. K. S. Tiwari, and D. K. Shrivastava, "Techniques for evaluation of medicinal plant products as antimicrobial agent: current methods and future trends," Journal of Medicinal Plant Research, vol. 4, no. 2, pp. 104-111, 2010.

[42] Z. L. Liu, Q. He, S. S. Chu, C. F. Wang, S. S. Du, and Z. W. Deng, "Essential oil composition and larvicidal activity of Saussurea lappa roots against the mosquito Aedes albopictus (Diptera: Culicidae)," Parasitology Research, vol. 110, no. 6, pp. 2125-2130, 2012.

[43] N. Anwer, M. A. Waqar, M. Iqbal, M. Mushtaq, and A. Sobia, "Phytochemical analysis, free radical scavenging capacity and antimicrobial properties of Impatiens bicolor plant,"
International Food Research Journal, vol. 20, no. 1, pp. 99-103, 2013.

[44] A. Perez, M. Orozeo, V. Rivas, and N. Waksman, "Experimental design to determine the factors affecting the preparation of extracts for antibacterial use," Natural Products Communication, vol. 3, no. 3, pp. 363-368, 2008.

[45] J. D. Phillipson and M. J. O. Neill, "New leads to the treatment of protozoal infections based on natural product molecules," Acta Pharmaceutica Nordica, vol. 1, pp. 131-144, 1987.

[46] S. A. Hayek and S. A. Ibrahim, "Antimicrobial activity of xoconostle pears (opuntia matudae) againstEscherichia coliO157:H7 in laboratory medium," International Journal of Microbiology, vol. 2012, pp. 1-6, 2012.

[47] S. Balakumar, S. Rajan, T. Thirunalasundari, and S. Jeeva, "Antifungal activity of Ocimum sanctum Linn. (Lamiaceae) on clinically isolated dermatophytic fungi," Asian Pacific Journal of Tropical Medicine, vol. 4, no. 8, pp. 654-657, 2011.

[48] M. R. Pandian, G. S. Banu, and G. Kumar, "Antimicrobial activities of natural honey from medicinal plants on antibiotic resistant strains of bacteria," Asian Journal of Microbiology Biotechnology and Environmental Sciences, vol. 9, no. 2, pp. 219-222, 2007.

[49] K. Srinivasan, "Antioxidant potential of spices and their active constituents," Critical Reviews in Food Science and Nutrition, vol. 54, no. 3, pp. 352-372, 2014.

[50] O. O. Olajuyigbe, A. A. Olajuyigbe, and A. J. Afolayan, "Ultrastructure and X-ray microanalysis of the antibacterial effects of stem bark ethanol extract of Acacia mearnsii de wild against some selected bacteria," Journal of Pure and Applied Microbiology, vol. 12, no. 4, pp. 2217-2228, 2018.

[51] A. A. Olajuyigbe, O. O. Olajuyigbe, and R. M. Coopoosamy, "Interaction of Ziziphus mucronata subsp. mucronata methanol extract and first-line antibiotics is synergistic in vitro through production of reactive oxygen species," Journal of Tropical Medicine, vol. 2020, pp. 1-9, 2020.

[52] L. Ganora, Herbal Constituents: Foundations of Phytochemistry, Herbal Chem Press, Louisville, CO, USA, 2008.

[53] R. E. Uzeh and D. O. Oguntosin, "Efficacy of essential oils from some African spices against two strains of Bacillus cereus isolated from vegetable salad," Journal of Food Research, vol. 2, no. 6, pp. 48-54, 2013.

[54] S. Mickmaray and M. S. Al Aboody, "In vitro antioidant and batericidal efficacy of 15 common spices; novel therapeutics for urinary tract infections?" Medicina (Kaunas), vol. 55, no. 6, p. 289, 2019.

[55] A. D. Alanis, F. Calzada, J. A. Cervantes, J. Torres, and G. M. Ceballos, "Antimicrobial properties of some plants used in Mexican traditional medicine for the treatment of gastrointestinal disorders," Journal of Ethnopharmacology, vol. 100, no. 1-2, pp. 153-157, 2005.

[56] L. S. Wei, M. Najiah, and W. Wendy, "In vitro antimicrobial activity of Colocasia esculenta extract against Vibrio spp," Journal of Agriculture, vol. 42, pp. 5-7, 2006.

[57] T. A. Akinyele, O. O. Okoh, D. A. Akinpelu, and A. I. Okoh, "In-Vitro antibacterial properties of crude aqueous and n-hexane extracts of the husk of cocos nucifera," Molecules, vol. 16, no. 3, pp. 2135-2145, 2011.

[58] J. L. Rios and M. C. Recio, "Medicinal plants and antimicrobial activity," Journal of Ethnopharmacology, vol. 100, no. 1-2, pp. 80-84, 2005.

[59] W. Fabry, P. O. Okemo, and R. Ansorg, "Antibacterial activity of East African medicinal plants," Journal of Ethnopharmacology, vol. 60, no. 1, pp. 79-84, 1998. 
[60] M. M. Cowan, "Plant products as antimicrobial agents," Clinical Microbiology Reviews, vol. 12, no. 4, pp. 564-582, 1999.

[61] M. Simões, R. N. Bennett, and E. A. S. Rosa, "Understanding antimicrobial activities of phytochemicals against multidrug resistant bacteria and biofilms," Natural Product Reports, vol. 26, no. 6, pp. 746-757, 2009. 